\title{
Struktur Komunitas Dan Panjang Koloni Karang Keras Di Perairan Kabupaten Bolaang Mongondow, Provinsi Sulawesi Utara
}

\author{
Community Structure and Length of Hard Coral Colonies in the waters of Bolaang \\ Mongondow Regency, North Sulawesi Province
}

\author{
${ }^{1}$ Jemmy Souhoka \\ ${ }^{1}$ Loka Konservasi Bita Laut Bitung-LIPI \\ E-mail:koral_js@yahoo.com
}

\begin{abstract}
ABSTRAK
Karang keras merupakan salah satu komponen utama pembentuk ekosistem terumbu karang dan mempunyai peranan yang sangat penting dalam memberikan sumbangsih bagi organisma yang ada di sekitarnya maupun yang ada di dalamnya. Tujuan penelitian ini untuk mengatahui struktur dan panjang koloni karang keras di perairan Kabupaten Bolaang Mongondow. Penelitian ini telah dilakukan pada bulan Pebruari 2019 di 7 lokasi dengan menggunakan metode transek garis.Hasil Analisamenunjukkan keanekaragaman jenis $(\mathrm{H})$ tertinggi sebesar 1,17 ditemukan di Stasiun 1. Kemerataan jenis (E) tertinggi sebesar 0,86 di Stasiun 1 dan dominansi jenis (D) tertinggi sebesar 0,20 di Stasiun 7. Persentase tutupan karang keras tertinggi ditemukan di Stasiun 3 sebesar 86,24\% dengan jumlah jenis karang keras sebanyak 90 jenis. Panjang koloni karang keras tertinggi dari jenis Porites cylindrica $6523 \mathrm{~cm}$ atau $23,93 \%$ dari total panjang karang keras seluruh stasiun penelitian.
\end{abstract}

Kata kunci : Struktur komunitas,karang keras, Bolang Mongondow.

\section{ABSTRACT}

Hard corals is one important component to structure the coral reef ecosystem and play a significant role for its marine life and its surrounding. The aim of research is to study the community structure of hard corals at Bolaang Mongondow District waters. This research was conducted in February 2019 at seven location using the line intersep transect method. The result of this study showed the highest diversity index 1,17 at Station 1. The highest evenness index (E) 0,86 at Station 1 and the highest dominancy index (D) 0,20 at Station 7. The highest percentage of coral coverage is 86,24\% at Station 3 with totals of 90 species of hard corals. The measuring hard corals colony from Porites cylindrica species $6523 \mathrm{~cm}$ or a totals of 23,93\% hard corals at research station.

Keywords : Community structure, hard coral, Bolaang Mongondow. 


\section{Pendahuluan}

Kabupaten Bolaang Mongondow terletak di provinsi Sulawesi Utara dan berbatasan dengan provinsi Gorontalo dengan ibukota kabupaten adalah Lolak. Luas kabupaten Bolaang Mongondow sebesar 3.506,24 $\mathrm{km}^{2}$ dengan jumlah penduduk 233.189 jiwa. Perairan kabupaten Bolaang Mongondo memiliki luas $\pm 3.517,47 \mathrm{~km}^{2}$ dengan jumlah penduduk sebanyak 246.282 jiwa yang menempati 17 kecamatan. Pesisir pantai kabupaten Bolaang Mongondow memiliki tiga ekosistem besar yakni ekosistem terumbu karang, ekosistem bakau dan ekosistem lamun.Secara astronomis, kabupaten Bolaang Mongondow terletak pada koordinat $00^{\circ} 15^{\prime} 46^{\prime \prime}$ -

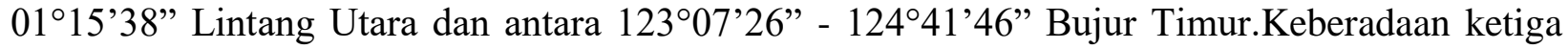
ekosistem pesisir ini memberikan gambaran tentang kehadiran berbagai organisma yang mendiaminya maupun yag berasosiasi dalam berbagai kepentingan seperti mencari makan (food migration), memijah (nursery ground), berlindung dari predator dan membesarkan diri.

Terumbu karang merupakan ekosistem pesisir yang dijumpai hampir di seluruh perairan pantai kabupaten Bolaang Mongondow dan mempunyai peranan penting bagi kepentingan masyarakat pesisir (nelayan) dalam memanfaatkan laut sebagai salah satu areal penangkapan ikan dan organisma ekonomis lainnya.Komponen utama pembentuk ekosistem terumbu karang yaitu karang keras dan merupakan organisma bentik yang cukup dominan dan mempunyai karakteristik yang unik. Karang keras termasuk dalam kelas Anthozoa, bangsa Scleractinia (Ditlev, 1980) dan ditemukan hampir di semua perairan tropis (Chave,1973). Karang keras biasanya hidup pada perairan dangkal, kurang dari kedalaman 40m (Sukarno et al, 1981) dan tidak dapat berkembang dengan baik pada kedalaman lebih dari 50-70m (Nybakken, 1992). Kehadiran karang keras di perairan kabupaten Bolaang Mongondow selain sebagai tujuan perikanan juga memberikan nilai tambah sebagai destinasi wisata bahari yang memiliki keindahan bawah air yang sangat menarik seperti di pulau Molosing dan perairan pulau Tiga.

Pembangunan infrastruktur pada bagian pesisir pantai sepanjang kabupaten Bolaang Mongondow dalam rangka membenahi kawasan Lolak sebagai ibukota kabupaten yang baru, perlu didukung oleh perencanaan lingkungan yang tepat. Dampak yang diakibatkan oleh analisis mengenai pemanfaatan dan penggunaan lingkungan yang tidak tepat akan berpengaruh pada kondisi dan keberadaan jenis-jenis karang keras yang ada di ekosistem terumbu karang yang ada disekitarnya.

Keanekaragaman jenis karang keras perairan kabupaten Bolaang Mongondow berdasarkan data citra satelit menunjukkan sebaran yang cukup luas dan terfokus di perairan pulau-pulau Tiga dan sekitarnya. Sayangnya belum banyak informasi mengenai jenis-jenis karang karang keras, beberapa aspek komunitas dan kondisinya yang diungkapkan. Untuk itu penelitian ini dilakukan dengan tujuan untuk melihat struktur komunitas dan panjang kolonikarang keras di perairan kabupaten Bolaang Mongondow. Hasil penelitian ini diharapkan dapat menambah perbendaraan jenis-jenis karang keras dan strukturnya, serta ukuran koloni karang keras dalam ekosistem terumbu karang di perairan kabupaten Bolaang Mongondow.

\section{Metode Penelitian}

\subsection{Waktu dan Tempat penelitian}

Penelitian struktur komunitas karang keras telah dilakukan pada bulan Pebruari 2019 berlokasi di perairan beberapa desa pesisir pantai kabupaten Bolang Mongondow, provinsi Sulawesi Utara. Pengamatan struktur komunitas karang keras berlangsung di 7 (tujuh) lokasi penelitian yaitu Stasiun 1 (P. Molosing selatan), Stasiun 2 (P. Molosing barat), Stasiun 3 (Pulau 


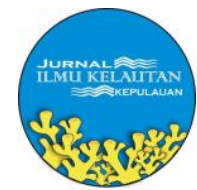

Tiga 1), Stasiun 4 (Pulau Tiga 2), Stasiun 5 (Pulau Tiga 3), Stasiun 6 (DPL Posianga 1) dan Stasiun 7 (Tg. Tungku). Penentuan stasiunpenelitian didasarkan atas hasil pengamatan kualitatif secara visual, yaitu dengan menggunakan Global Positioning System (GPS) pada areat yang memiliki terumbu karang yang luas, data citra satelit dan ditambah dengan informasi nelayan setempat. Selengkapnya lokasi dan posisi stasiun-stasiun penelitian ditampilkan dalam Gambar 1 dan Tabel 1.

\subsection{Bahan dan data}

Bahan yang diperlukan dalam penelitian ini antara lain : perahu (speed boat), tabung selam (scuba), kelengkapan selam (dive) seperti masker, BC (pelampung), baju selam (weit suit), sepatu selam (coral boot), fin, meteran rol ukuran 100m, kertas (underwater paper), pinsil dan GPS (global positioning system). Data sekunder yang dibutuhkan yaitu tabel pasang surut, peta lokasi penelitian dan literatur mengenai perairan kabupaten Bolaang Mangondo dan sekitarnya. Data primer diperoleh berdasarkan hasil transek yang dilakukan secara insitu dengan pendekatan metodologi "Line Intersept Transect" (LIT).

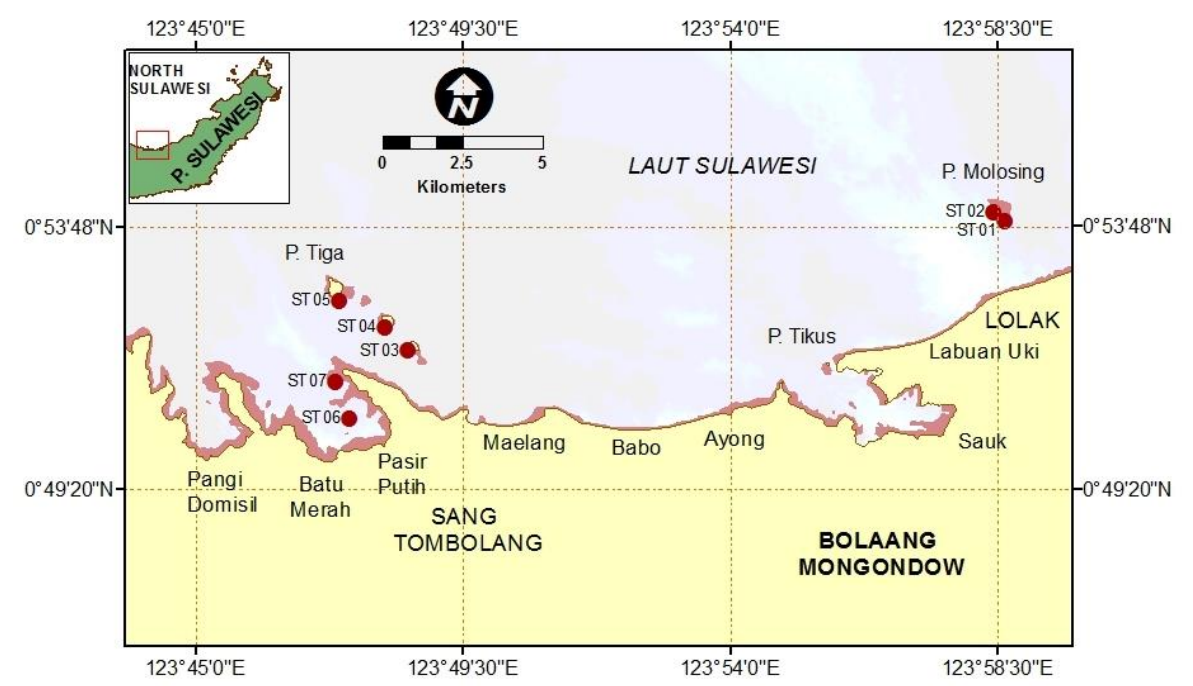

Gambar 1. Peta lokasi penelitian karang keras di perairan Kabupaten Bolaang Mangondo, Pebruari 2019.

Tabel 1. Posisi lokasi penelitian karang keras di perairan Kabupaten Bolaang Mangondo, Pebruari 2019.

\begin{tabular}{lrrl}
\hline Stasiun & Lat $(\mathrm{N})$ & Long $(\mathrm{E})$ & Lokasi \\
\hline ST.01 & 0.89846 & 123.97725 & P. Molosing Selatan \\
ST.02 & 0.90108 & 123.97401 & P. Molosing Barat \\
ST.03 & 0.86166 & 123.80953 & P. Tiga_1 \\
ST.04 & 0.86842 & 123.80282 & P. Tiga_2 \\
ST.05 & 0.87595 & 123.79015 & P. Tiga 3 \\
ST.06 & 0.84248 & 123.79282 & DPL Posianga \\
ST.07 & 0.85288 & 123.78899 & Tg. Tungku \\
\hline
\end{tabular}




\subsection{Metode penelitian dan Analisis data}

Metode penelitian yang digunakan dalam kegiatan riset ini yaitu metode transek garis (line intersept transect) sebagaimana yang dikemukakan oleh Loya (1972) dan English et al. (1997). Teknis pelaksanaan metode transek garis yaitu dengan cara melakukan penarikan meteran sepanjang $50 \mathrm{~m}$ sejajar garis pantai pada kedalaman antara 5-7 m yang dilakukan pada tiap stasiun penelitian. Diasumsikan bahwa pada kedalaman ini populasi karang keras cukup padat. Karang keras dan komponen bentik yang terlewati garis transek dicatat sampai tingkat sentimeter (cm). Data komposisi jenis karang keras diperoleh secara koleksi bebas, yaitu spesies karang keras diambil tidak hanya di garis transek, tetapi juga di luar garis transek, dimulai dari kedalaman 0,5 m sampai batas pertumbuhan karang keras.

Analisis data berupa identifikasi spesies karang keras dilakukan langsung di lapangan atau diidentifikasi di laboratorium Loka Konservasi Biota Laut LIPI Bitung. Spesies yang belum diketahui jenisnya dilakukan identifikasi dengan mengacu pada buku identifikasi dari Veron (1986), Huang \& Mao (2012) dan Suharsono (2010). Persentase tutupan karang keras dianalisis dengan menggunakan MS Excel, sedangkan keanekaragaman jenis $(\mathrm{H})$, kemerataan jenis $(\mathrm{j})$ dan dominansi (D), dihitung dengan formula dari Odum (1971) sebagai berikut:

1). Indeks keanekaragaman jenis $(\mathrm{H})$

$$
\mathrm{H}=-\sum(\mathrm{ni} / \mathrm{N}) \log (\mathrm{ni} / \mathrm{N})
$$

Selanjutnya nilai $\mathrm{H}$ digunakan untuk melihat status keanekaragaman sebagai berikut:

$$
\begin{array}{ll}
0<\mathrm{H} \leq 1 & : \text { rendah (tidak stabil) } \\
1<\mathrm{H} \leq 2 & \text { : sedang (moderat) } \\
\mathrm{H}>2 & \text { : tinggi (stabil) }
\end{array}
$$

Kriteria produktivitas berdasarkan nilai Indeks keanekaragaman jenis (Stodart \& Johnson dalam Manuputty, 1990).

$$
\begin{array}{ll}
0,00-0,25 & \text { : tidak produktif } \\
0,25-0,50 & \text { : kurang produktif } \\
0,50-0,75 & \text { : sedang produktif } \\
0,75-1,00 & \text { : produktif } \\
\text { Diatas } 1,00 & \text { : sangat produktif } \\
\text { 2). Indeks kemerataan jenis }(\mathrm{E}) \\
\mathrm{E}=\mathrm{H} / \log \mathrm{S}
\end{array}
$$

Selanjutnya nilai E digunakan untuk melihat kestabilan komunitas yaitu:

$$
\begin{array}{ll}
0<\mathrm{E} \leq 0,50 & : \text { komunitas tertekan } \\
0,50<\mathrm{E} \leq 0,75 & : \text { komunitas labil } \\
0,75<\mathrm{E} \leq 1,00 & : \text { komunitas stabil }
\end{array}
$$


3). Indeks dominansi (D)

$$
\mathrm{D}=(\mathrm{ni} / \mathrm{N})^{2}
$$

Selanjutnya nilai $\mathrm{D}$ digunakan untuk melihat dominansi sebagai berikut:

$$
\begin{array}{ll}
0<\mathrm{D} \leq 0,50 & : \text { dominansi rendah } \\
0,50<\mathrm{D} \leq 0,75 & : \text { dominansi sedang } \\
0,75<\mathrm{D} \leq 1,00 & : \text { dominansi tinggi }
\end{array}
$$

$$
\begin{aligned}
& \text { 4). Persentase tutupan } \\
& \% \text { tutupan }=\frac{\text { Panjang tiap koloni }}{\text { Panjang transek }} \times 100
\end{aligned}
$$

Kriteria pengkatagorian penentuan status kondisi terumbu karang (Gomez \& Alcala, 1978)

$$
\begin{array}{ll}
0-24,9 \% & : \text { kategori jelek } \\
25-49,9 \% & : \text { kategori sedang } \\
50-74,9 & : \text { kategori baik } \\
75-100 & : \text { kategori sangat baik }
\end{array}
$$

Keterangan :

$\mathrm{H}$ : nilai keanekaragaman jenis

ni: jumlah persentase tutupan jenis

$\mathrm{N}$ : jumlah total persentase tutupan

$\mathrm{j}$ : nilai kemerataan jenis

S: total jumlah jenis

D: nilai dominansi

\section{III.Hasil dan Pembahasan}

Secara umum lokasi pengamatan karang keras perairan kabupaten Bolaang Mongondow terfokus di perairan pulau Molosing dan sekitarnya sampai perairan pulau Tiga. Bagian pantai, khususnya didaratan pulau Sulawesi didominasi oleh beberapa jenis tumbuhan pantai, pohon kelapa dan pemukiman penduduk, sedangkan di lokasi pengamatan yang berupa pulau-pulau kecil tidak ditemukan adanya areal pemukiman penduduk tetapi didominasi oleh vegetasi tumbuhan pantai. Bentuk profil dasar perairan tiap lokasi pengamatan (Gambar 2),memiliki kontur dasar yang hampir sama yaitu berbentuk sedikit miring dan panjang rataan terumbu berkisar dari 2,5-7m. Khususnya untuk Stasiun 7 bentuk dasarnya dimulai dari rataan terumbu (reef flat) dengan panjang lintasan 30mdan lebar $25 \mathrm{~m}$, selanjutnya dasar perairannya agak miring mencapai $45^{\circ}$ sampai kedalaman $20 \mathrm{~m}$. Lokasi Stasiun 7 diduga merupakan sebuah pulau kecil yang telah terkikis oleh ombak dalam waktu yang cukup lama dan sudah membentuk sebuah lagon dengan daratan pulau Sulawesi (mainland). Kondisi perairan pada saat pengambilan data sedikit berombak dan berarus karena dipengaruhi oleh angin musim utara. Parameter lingkungan yang diukur meliputi temperatur, salinitas dan kecerahan nilainya (Gambar 3), dengan rerata nilai temperatur sebesar $29,87^{\circ} \mathrm{C}$, salinitas sebesar $32,07 \%$ dan kecerahan sebesar $12,36 \mathrm{~m}$. 
JURNAL ILMU KELAUTAN KEPULAUAN, 2 (2) ;55-73, DESEMBER 2019

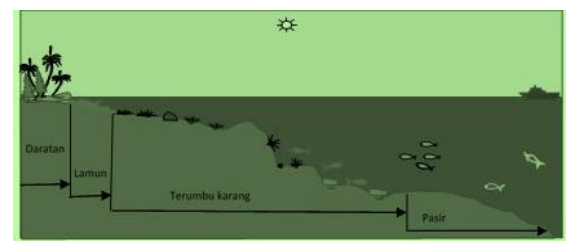

(Stasiun 1)

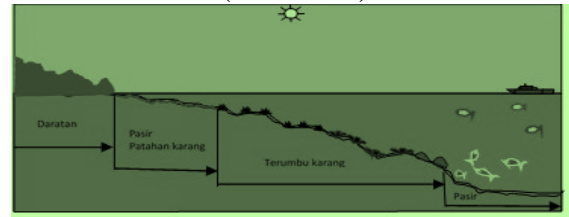

(Stasiun 4)

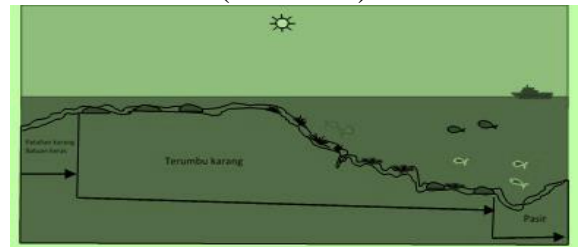

(Stasiun 7)

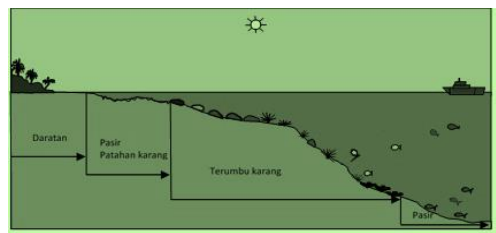

(Stasiun 2)

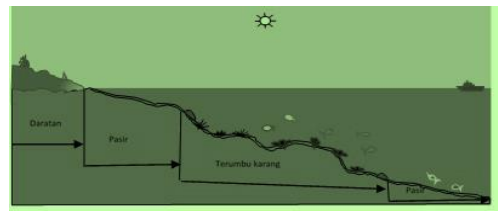

(Stasiun 5)

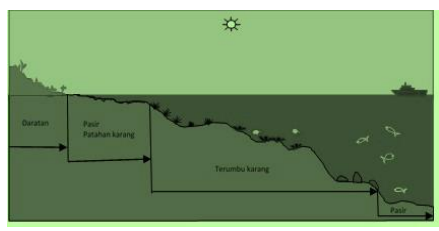

(Stasiun 3)

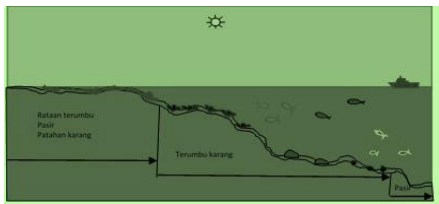

(Stasiun 6)

Gambar 2. Bentuk profil dasar perairan tiap stasiun pengamatan perairan Kabupaten Bolaang Mongondow, Pebruari 2019.

Parameter lingkungan perairan Kabupaten Bolaang Mongondow, Pebruari 2019

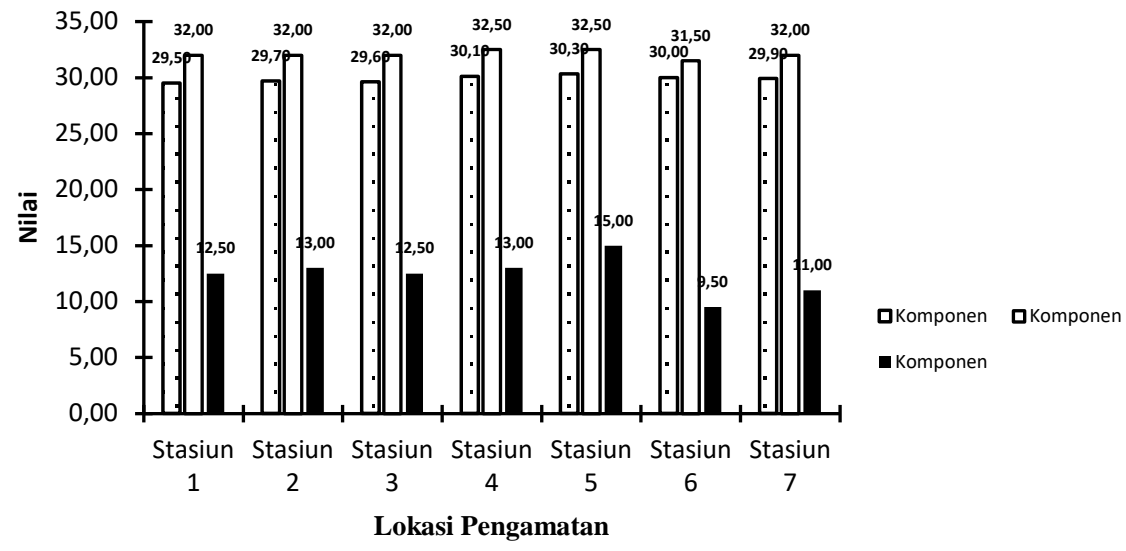

Gambar 3. Parameter lingkungan perairan Kabupaten Bolaang Mongondow, Pebruari 2019.

Hasil identifikasi jenis karang keras di perairan pesisir kabupaten Bolaang Mongondow, berdasarkan sensus visual secara bebas mulai dari kedalaman $0,5 \mathrm{~m}$ sampai batas pertumbuhan karang keras pada kedalaman tertentu, telah ditemukan sebanyak 90 jenis yang termasuk dalam 42 marga dan 13 suku (Tabel 2). 
JURNAL ILMU KELAUTAN KEPULAUAN, 2 (2) ;55-73, DESEMBER 2019

Tabel 2. Jenis-jenis karang keras yang teridentifikasi secara visual di perairan Kabupaten Bolaang Mongondow, Pebruari 2019.

\begin{tabular}{|c|c|c|c|c|c|c|c|c|}
\hline \multirow{2}{*}{ No } & \multirow{2}{*}{ Suku Jenis } & \multicolumn{7}{|c|}{ Lokasi Penelitian } \\
\hline & & St.1 & St.2 & St.3 & St.4 & St.5 & St.6 & St.7 \\
\hline I & ACROPORIDAE & & & & & & & \\
\hline 1. & Acropora brueggemanni & + & + & + & + & - & - & - \\
\hline 2. & Acropora clathrata & + & - & - & - & - & - & - \\
\hline 3. & Acropora divaricata & + & + & - & - & - & - & - \\
\hline 4. & Acropora formosa & - & - & + & - & + & + & + \\
\hline 5. & Acropora humilis & - & + & + & - & - & - & + \\
\hline 6. & Acropora hyacinthus & + & - & - & - & - & - & - \\
\hline 7. & Acropora intermedia & + & + & - & - & - & - & - \\
\hline 8. & Acropora millepora & + & - & - & - & - & - & - \\
\hline 9. & Acropora nobillis & + & + & - & - & - & - & - \\
\hline 10. & Acropora palifera & + & - & - & + & - & + & - \\
\hline 11. & Acropora pulchra & - & - & + & - & - & - & - \\
\hline 12. & Acropora sarmentosa & + & - & - & - & - & - & - \\
\hline 13. & Acropora tenuis & + & - & - & - & - & - & - \\
\hline 14. & Acropora yongei & + & - & - & - & - & - & - \\
\hline 15. & Astreopora gracillis & - & - & - & - & - & + & - \\
\hline 16. & Astreopora myriophthalma & + & + & - & - & - & - & - \\
\hline 17. & Montipora capricornis & + & - & - & - & - & - & - \\
\hline 18. & Montipora foliose & - & - & - & - & - & - & + \\
\hline 19. & Montipora hoffmeisteri & - & + & - & + & - & + & + \\
\hline 20. & Montipora informis & + & + & - & - & - & - & - \\
\hline 21. & Montipora monticulosa & - & - & - & + & - & - & - \\
\hline II & AGARICIIDAAE & & & & & & & \\
\hline 22. & Coeloseris mayeri & + & + & + & + & - & - & - \\
\hline 23. & Leptoseris explanata & - & + & - & - & - & + & + \\
\hline 24. & Leptoseris yabei & + & - & - & - & - & - & - \\
\hline 25. & Pachyseris rugosa & + & + & + & + & - & + & - \\
\hline 26. & Pavona deccusatta & - & - & + & - & - & - & - \\
\hline III & CARYOPHYLLIIDAE & & & & & & & \\
\hline 27. & Euphyllia ancora & + & + & + & + & + & + & + \\
\hline 28 & Euphyllia divisa & + & - & - & + & - & - & - \\
\hline 29. & Euphyllia glabrescens & + & - & - & + & - & - & - \\
\hline 30. & Physogyra lichtensteini & - & - & - & + & + & - & - \\
\hline 31. & Plerogyra simplex & + & - & - & + & - & - & - \\
\hline 32. & Plerogyra sinuosa & - & - & + & - & - & - & - \\
\hline
\end{tabular}


JURNAL ILMU KELAUTAN KEPULAUAN, 2 (2) ;55-73, DESEMBER 2019

IV DENDROPHYLLIIDAE

33. Turbinaria mesenterina

34. Turbinaria reniformis

$\mathrm{V}$ FAVIIDAE

35. Caulastrea tumida

36. Cyphastrea chalcidicum

37. Cyphastrea microphthalma

38. Diploastrea heliopora

39. Echinophora lamellosa

40. Favia maxima

41. Favia matthaii

42. Favia pallida

43. Favia speciosa

44. Favia stelligera

45. Favites abdita

46. Favites complanata

47. Favites flexuosa

48. Favites halicora

49. Goniastrea edwardsi

50. Goniastrea pectinata

51. Montastrea curta

VI FUNGIIDAE

52. Ctenactis echinata

53. Fungia concinna

54. Fungia fungites

55. Fungia horrida

56. Fungia moluccensis

57. Fungia paumotensis

58. Fungia scutaria

59. Halomitra pileus

60. Heliofungia actiniformis

61. Herpolitha limax

VII MERULINIDAE

62. Hydnophora rigida

63. Merulina ampliata

VIII MUSSIDAE

64. Acanthastrea hillae

65. Cynarina lacrymalis

66. Lobophyllia corymbosa

67. Lobophyllia hemprichii

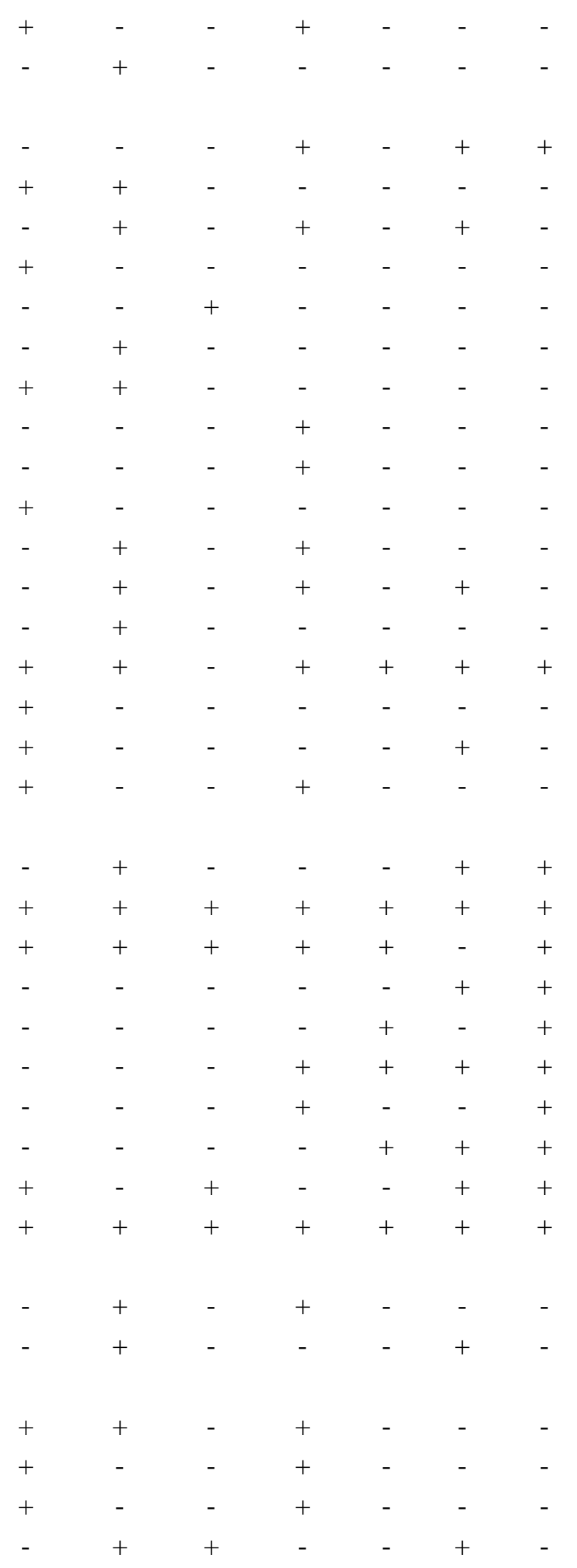


JURNAL ILMU KELAUTAN KEPULAUAN, 2 (2) ;55-73, DESEMBER 2019

68. Symphyllia recta

69. Symphyllia radians

70. Galaxea astreata

71. Galaxea fascicularis

IX PECTINIIDAE

72. Mycedium elephantotus

73. Oxypora lacera

74. Pectinia lactuca

75. Pectinia teres

X POCILLOPORIDAE

76. Pocillopora verrucossa

77. Seriatophora caliendrum

78. Seriatophora hystrix

79. Stylophora pistillata

XI PORITIDAE

80. Alveopora catalai

81. Goniopora columna

82. Goniapora lobata

83. Porites cylindrica

84. Porites lichen

85. Porites lobata

86. Porites lutea

87. Porites nigrecens

88. Porites rus

XII HELIOPORIDAE

89. Heliopora coerulea

XIII MILLEPORIDAE
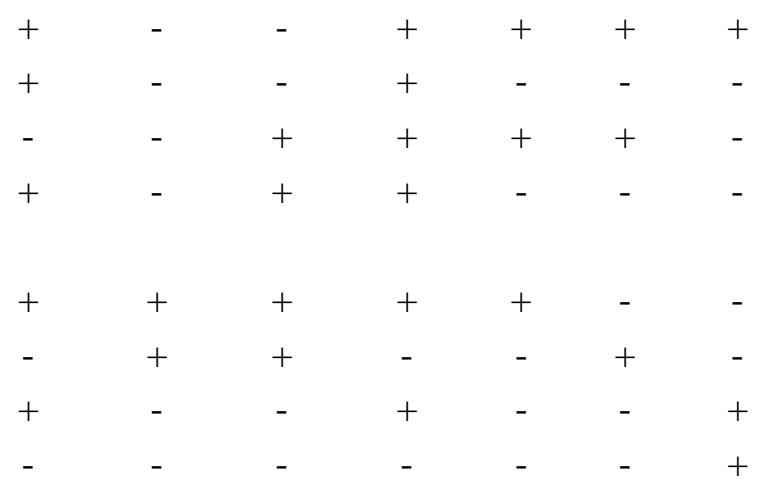

$\begin{array}{rrrrrrr}+ & + & - & + & - & + & - \\ + & + & + & + & + & + & + \\ + & + & + & + & + & + & + \\ + & + & + & + & + & + & -\end{array}$

\begin{tabular}{lllllll}
- & - & - & - & - & + & + \\
+ & - & - & - & - & + & - \\
+ & - & - & - & - & - & - \\
+ & + & + & + & + & + & + \\
+ & - & - & - & - & - & - \\
+ & + & - & + & - & - & - \\
+ & + & + & + & + & + & + \\
+ & + & + & + & + & + & + \\
+ & + & + & + & + & + & + \\
& & & & & & \\
- & - & + & + & - & + & - \\
- & + & + & + & - & + & - \\
\hline
\end{tabular}

Keterangan : (St.1...St.7) : stasiun penelitian , (+) ; ditemukan. (-) : tidak ditemukan.

Analisis struktur komunitas karang keras dengan menggunakan data jumlah jenis dan jumlah individu karang keras berdasarkan data hasil transek sebagaimana pada Tabel 3.Berdasarkan data transek yang dilakukan pada tiap stasiun penelitian, selanjutnya dianalisisuntuk memperoleh nilai persentase tutupan karang keras dan komponen bentik lainnya sebagaimana hasilnya tertuang dalam Tabel 4. Panjang total koloni karang keras yang ditemukan di perairan kabupaten Bolaang Mongondow sebesar $27.258 \mathrm{~cm}$, dimana panjang total tiap suku karang keras (Tabel 5). 
Tabel 3. Jumlah individu dan jenis karang keras yang ditemukan di garis transek tiap stasiun penelitian lokasi perairan Kabupaten Bolaang Mongondow, Pebruari 2019.

\begin{tabular}{|c|c|c|c|c|c|c|c|c|}
\hline No & Jenis Karang & St. 1 & St.2 & St.3 & St.4 & St.5 & St.6 & St.7 \\
\hline 1. & Acropora brueggemanni & 16 & 2 & 19 & 1 & & & \\
\hline 2. & Acropora clathrata & 1 & & & & & & \\
\hline 3. & Acropora formosa & & & 3 & & 1 & 1 & 2 \\
\hline 4. & Acropora humilis & & 1 & 2 & & & & 1 \\
\hline 5. & Acropora hyacinthus & 3 & & & & & & \\
\hline 6. & Acropora millepora & 1 & & & & & & \\
\hline 7. & Acropora palifera & 4 & & & 2 & & 1 & \\
\hline 8. & Acropora pulchra & & & 1 & & & & \\
\hline 9. & Acropora tenuis & 2 & & & & & & \\
\hline 10. & Astreopora gracillis & & & & & & 5 & \\
\hline 11. & Cyphastrea microphthalma & & & & & & 7 & \\
\hline 12. & Diploastrea heliopora & 1 & & & & & & \\
\hline 13. & Echinophora lamelossa & & & 16 & & & & \\
\hline 14. & Euphyllia ancora & 1 & 2 & 1 & & & & 2 \\
\hline 15 . & Favia maxima & & 1 & & & & & \\
\hline 16. & Favia pallida & & & & 1 & & & \\
\hline 17. & Favia speciosa & & & & 2 & & & \\
\hline 18. & Favites abdita & & 2 & & 1 & & & \\
\hline 19. & Favites complanata & & 1 & & 3 & & 1 & \\
\hline 20. & Favites flexuosa & & 1 & & & & & \\
\hline 21. & Favites halicora & 2 & 1 & & 3 & 1 & 1 & 1 \\
\hline 22. & Fungia concinna & 2 & 14 & 4 & 1 & 1 & 2 & 6 \\
\hline 23. & Fungia fungites & 1 & 12 & 2 & 1 & 4 & & 2 \\
\hline 24. & Fungia scutaria & & & & 2 & & & \\
\hline 25 . & Galaxea astreata & & & 1 & 1 & 1 & 3 & \\
\hline 26. & Goniapora lobata & 1 & & & & & & \\
\hline 27. & Goniopora columna & 1 & & & & & 1 & \\
\hline 28. & Heliofungia actiniformis & 1 & & 1 & & & 1 & 1 \\
\hline 29. & Heliophora coerulea & & & 10 & 9 & & 1 & \\
\hline 30. & Herpolitha limax & 1 & 7 & 2 & 3 & 1 & 1 & 2 \\
\hline 31. & Lobophyllia hemprichi & & 1 & 1 & & & 1 & \\
\hline 32. & Merulina ampliata & & 1 & & & & 2 & \\
\hline 33. & Millepora intrincata & & 3 & 10 & 1 & & 4 & \\
\hline 34. & Montastrea curta & 1 & & & 5 & & & \\
\hline 35. & Montipora foliosa & & & & & & & 2 \\
\hline 36. & Montipora hoffmeisteri & & 1 & & 2 & & 1 & 1 \\
\hline
\end{tabular}


JURNAL ILMU KELAUTAN KEPULAUAN, 2 (2) ;55-73, DESEMBER 2019

1

\begin{tabular}{|c|c|c|c|c|c|c|c|c|}
\hline 37. & Montipora monticulosa & & & & 1 & & & \\
\hline 38. & Oxypora lacera & & 2 & 1 & & & 2 & \\
\hline 39. & Pavona deccusssata & & & 2 & & & & \\
\hline 40. & Pectinia lactuca & 1 & & & 1 & & 1 & 3 \\
\hline 41. & Pectinia teres & & & & & & & 1 \\
\hline 42. & Physogyra lichtensteini & & & & & 1 & & \\
\hline 43. & Plerogyra sinuosa & & & 2 & & & & \\
\hline 44. & Pocillopora verrucossa & 3 & 3 & & 7 & & 1 & \\
\hline 45. & Porites cylindrica & & & & 2 & 12 & 34 & 25 \\
\hline 46. & Porites lobata & 2 & & & 4 & & & \\
\hline 47. & Porites lutea & 3 & 1 & & 24 & 1 & 4 & \\
\hline 48. & Porites nigrecens & 1 & 31 & & 21 & 11 & 5 & 6 \\
\hline 49. & Porites rus & & 26 & & 5 & 11 & & 4 \\
\hline 50. & Seriatophora caliendrum & & 1 & 1 & & & & 1 \\
\hline 51. & Seriatophora hystrix & 4 & 2 & 14 & & 1 & & 2 \\
\hline 52. & Styphora pistillata & & 2 & & 1 & & 6 & \\
\hline 53. & Symphyllia recta & 2 & & & 1 & & & \\
\hline \multicolumn{2}{|c|}{ Jumlah individu } & 55 & 118 & 93 & 105 & 46 & 86 & 62 \\
\hline \multicolumn{2}{|c|}{ Jumlah jenis } & 23 & 23 & 19 & 26 & 12 & 23 & 17 \\
\hline
\end{tabular}

Tabel 4. Nilai persentase tutupan (\%) komponen bentik lokasi penelitian perairan Kabupaten Bolaang Mongondow, Pebruari 2019.

\begin{tabular}{llccccccc}
\hline \multirow{2}{*}{ No } & \multicolumn{1}{c}{ Komponen Bentik } & \multicolumn{7}{c}{ Lokasi Penelitian } \\
\cline { 3 - 8 } & & St.1 & St.2 & St.3 & St.4 & St.5 & St.6 & St.7 \\
\hline 1. & Karang hidup (LC) & 85.80 & 84.20 & 86.24 & 63.40 & 78.70 & 69.12 & 77.70 \\
2. & Karang Acropora (AC) & 63.10 & 2.60 & 32.20 & 1.50 & 0.30 & 1.40 & 1.16 \\
3. & Karang Non-Acropora (NA) & 22.70 & 81.60 & 54.04 & 61.90 & 78.40 & 67.72 & 76.54 \\
4. & Karang mati (DC) & 0.00 & 0.00 & 0.00 & 0.00 & 0.00 & 0.00 & 0.00 \\
5. & Karang mati beralga (DCA) & 2.70 & 1.30 & 0.80 & 0.00 & 0.00 & 0.00 & 0.40 \\
6. & Karang lunak (SC) & 2.70 & 10.60 & 0.00 & 2.30 & 1.60 & 8.90 & 2.70 \\
7. & Sponges (SP) & 1.00 & 0.00 & 0.30 & 0.20 & 3.10 & 0.40 & 0.00 \\
8. & Fauna lain (OT) & 0.20 & 0.00 & 0.40 & 0.00 & 0.00 & 0.00 & 0.00 \\
9. & Fleshy seawed (FS) & 0.00 & 0.00 & 0.00 & 1.50 & 0.00 & 1.82 & 4.40 \\
10. & Patahan karang (R) & 5.80 & 3.90 & 11.76 & 28.80 & 16.60 & 15.76 & 13.00 \\
11. & Pasir (S) & 1.60 & 0.00 & 0.50 & 3.80 & 0.00 & 4.00 & 1.80 \\
12. & Pasir halus (SI) & 0.20 & 0.00 & 0.00 & 0.00 & 0.00 & 0.00 & 0.00 \\
13. & Batuan keras (RCK) & 0.00 & 0.00 & 0.00 & 0.00 & 0.00 & 0.00 & 0.00 \\
\hline Ketenyyyyyyyyyyyy
\end{tabular}

Keterangan : ( St.1...St.7) : stasiun penelitian. 
JURNAL ILMU KELAUTAN KEPULAUAN, 2 (2) ;55-73, DESEMBER 2019

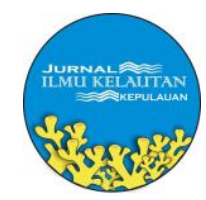

Tabel 5. Panjang total $(\mathrm{cm})$ tiap suku karang keras yang ditemukan di garis transek perairan Kabupaten Bolaang Mongondow, Pebruari 2019.

\begin{tabular}{|c|c|c|}
\hline No. & Suku & Panjang $(\mathrm{cm})$ \\
\hline 1. & Poritidae & 14761 \\
\hline 2. & Acroporidae & 5763 \\
\hline 3. & Faviidae & 2016 \\
\hline 4. & Fungiidae & 1416 \\
\hline 5. & Pocilloporidae & 1060 \\
\hline 6. & Helioporidae & 755 \\
\hline 7. & Milleporidae & 535 \\
\hline 8. & Pectiniidae & 355 \\
\hline 9. & Mussidae & 272 \\
\hline 10. & Caryophylliidae & 205 \\
\hline 11. & Agariciidaae & 75 \\
\hline 12. & Merulinidae & 45 \\
\hline \multicolumn{2}{|c|}{ Total panjang koloni } & 27258 \\
\hline
\end{tabular}

Hasil identifikasi jenis karang keras yang ditemukan secara visual di perairan kabupaten Bolaang Mongondow sebanyak 90 jenis yang berarti 15,25\% dari jumlah jenis karang keras yang ditemukan di Indonesia yang diperkirakan sebanyak 590 jenis (Suharsono,2010).Sedangkan jumlah marga karang keras yang ditemukan sebanyak 42 marga yang berarti $50 \%$ dari jumlah marga karang keras yang ditemukan di perairan Indo-Pasifik sebanyak 84 marga dan 35,29\% dari marga karang keras yang tersebar di dunia (119 marga) (Veron, 1986). Keberadaan jenisjenis karang keras di perairan kabupaten Bolaang Mongondow (Tabel 2) didominasi oleh 9 jenis yang frekuensi kehadirannya dapat ditemukan disemua stasiun pengamatan antara lain Euphyllia ancora, Fungia concinna, Herpolitha limax, Seriatophora caliendrum, Seriatophora hystrix, Porites cylindrica, Porites lutea, Porites nigrecens dan Porites rus.Secara umum jenis-jenis yang dominan ditemukan ini merupakan jenis karang keras yang umumnya ditemukan hampir seluruh perairan Indonesia (Suharsono, 2010) dan di perairan Indo-Pasifik (Veron, 1986).Euphyllia ancora merupakan jenis karang keras yang masuk dalam dalam suku Caryophylliidae yang menyebar hampir diseluruh perairan Indonesia(Suharsono, 2010) dan di perairan Bolaang Mongondow di temukan pada daerah yang terlindung seperti di Stasiun 2 dan Stasiun 3.Fungia concinna dan Herpolitha limax jenis karang keras yang masuk suku Fungiidae dan ditemukan umumnya di seluruh perairan Indonesia. Demikian juga karang keras jenis Porites cylindrica, Porites lutea, Porites nigrecens dan Porites rus masuk suku Poritidae dan merupakan karang keras yang dapat ditemukan di seluruh perairan Indonesia (Suharsono, 2010) dan menyebar hampir di seluruh perairan Australia termasuk Great Barrier Reef (Veron, 1986). Bentuk morfologi karang keras yang ditemukan di perairan Kabupaten Bolaang Mongondow (Gambar 4) lebih didominasi oleh karang bercabang (branching) (CB) non-Acropora sebanyak 197 individu (34,87\%), disusul karang jamur (mushroom) (CMR) sebanyak 95 individu (16,81\%), karang merayap (encruisting) (CE) sebanyak 66 individu (11,68\%), karang bercabang Acropora (ACB) 
sebanyak 49 individu (8,67\%), karang submasif (CS) sebanyak 48 individu (8,50\%) dan bentuk morfologi karang keras lainnya dibawah $8 \%$.

Jumlah jenis karang keras yang ditemukan di perairan kabupaten Bolaang Mongondow berdasarkan hasil sensus visual sebanyak 90 jenis. Jumlah ini kecil dibandingkan dengan yang ditemukan di perairan Lembata (NTT) sebanyak 313 jenis (Abrar et al, 2012), perairan Tobelo sebanyak 146 jenis (Souhoka, 2012) dan di perairan Tanjung Merah, Sulawesi Utara sebanyak 165 jenis (Souhoka, 2007). Tetapi bila dibandingkan dengan beberapa lokasi lain di perairan Indonesia ternyata jumlah jenis karang keras yang ditemukan di perairan kabupaten Bolaang Mongondow lebih banyak seperti di perairan Pulau Nias sebanyak 57 jenis (Siringoringo, 2010), Pulau Panjang Jepara sebanyak 54 jenis (Indarjo et al, 2004) dan Pulau Sekepal Lampung Selatan sebanyak 56 jenis (Widinugraheni, 1993).

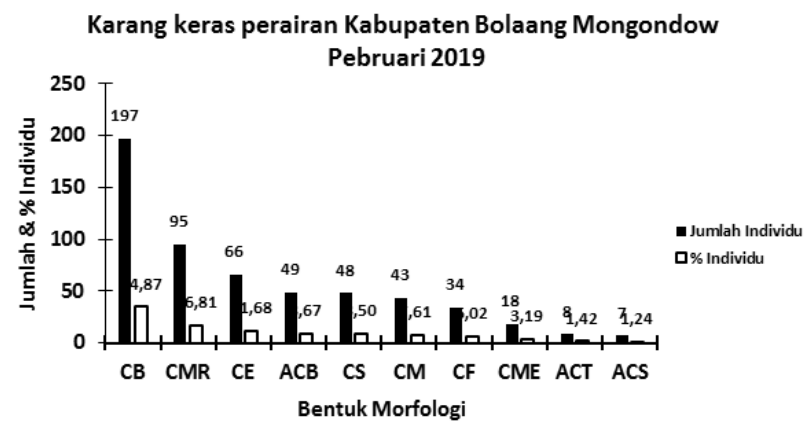

Gambar 4. Bentuk Morfologi karang keras yang ditemukan di perairan Kabupaten Bolaang Mongondow, Pebruari 2019.

Hasil analisis struktur komunitas karang keras menyangkut komponen indeks keanekaragaman jenis (H), kemerataan jenis (E) dan dominansi jenis (D) berdasarkan jumlah individu (Tabel 3) yang hasilnya sebagaimana pada Gambar 5, menunjukkan adanya variasi nilai setiap komponen untuk masing-masing stasiun pengamatan.

Lokasi penelitian perairan Kabupaten Bolaang Mongondow Pebruari 2019

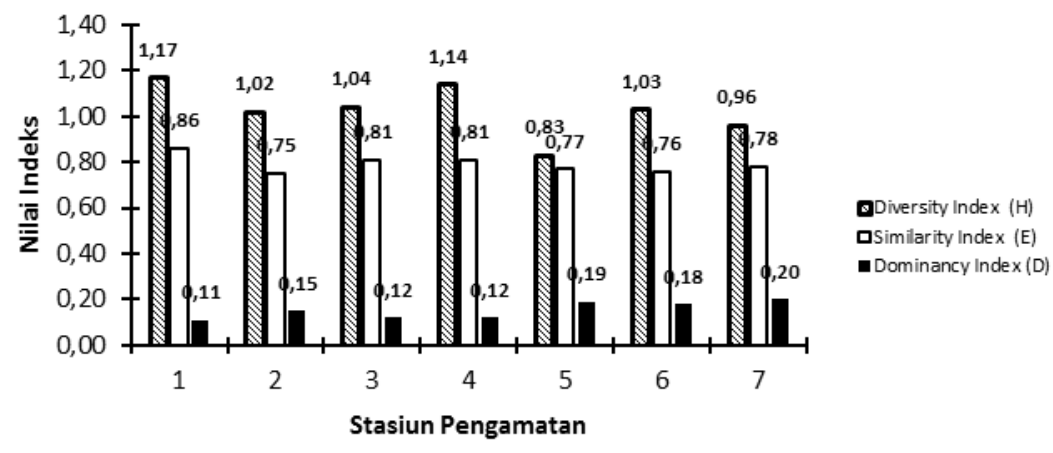

Gambar 5.Nilai indeks keanekaragaman jenis (H), indeks kemerataan jenis (E) dan indeks Dominansi (D) karang keras perairan Kabupaten Bolaang Mongondow, Pebruari 2019. 
Hasil indeks keanekaragaman jenis $(\mathrm{H})$ sebagaimana pada Gambar 5, menunjukkan variasi nilai antar stasiun dari 0,83 (Stasiun 5) sampai 1,17 (Stasiun 1). Tingginya nilai indeks keanekaragaman jenis $(\mathrm{H})$ di lokasi Stasiun 1 menunjukkan adanya jumlah jenis yang ditemukan cukup banyak dibandingkan dengan Stasiun 5.Tingginya nilai keanekaragaman jenis pada suatu komuntas terjadi jika komunitas tersebut disusun oleh banyak spesies dengan kelimpahan spesies satu sama lainnya sama atau hampir sama (Umar, 2013 dalam Hermanto, 2014). Jenis-jenis karang keras yang ditemukan di Stasiun 1 cukup bervariasi dengan jumlah individu terbanyak dari jenis Acropora brueggemanni, Acropora palifera, Seriatophora hystrix dan Acropora hyacinthus yang merupakan karang bercabang (coral branching) dan biasanya ditemukan pada perairan yang jernih. Perairan Stasiun 1 yang terletak di pulau Molosing bagian selatan memiliki nilai temperatur $\left(29,50^{\circ} \mathrm{C}\right)$, salinitas $(32,00 \%)$ dan kecerahan $(12,50 \mathrm{~m})$ (Gambar 3) sangat cocok untuk kehidupan karang keras, sebagaimana diungkapkan oleh Sukarno et al (1981) bahwa kosentrasi pertumbuhan karang keras pada umumnya berkisar pada salinitas 25 - 40\%o. Demikian juga Salm \& Clarck, (1989) menyatakan bahwa temperatur yang berkisar antara 25 $29^{\circ} \mathrm{C}$ pada laut dangkal perairan tropis sangat cocok untuk pertumbuhan karang keras. Dibandingkan dengan beberapa lokasi di Indonesia keanekaragaman jenis (H) lokasi ini lebih tinggi dari di perairan Selayar Sulawesi Selatan (1,07) (Souhoka, 2012), perairan pulau Tagulandang $(1,08)$ (Souhoka,2014) tetapi lebih kecil nilainya dibandingkan dengan lokasi pulau Panjang, Jepara sebesar 2,87 (Indarjo et al, 2004).Keanekaragaman jenis (H) perairan Stasiun 1 didominasi oleh karang keras marga Acropora jenis Acropora brueggemanni, Acropora palifera, Acropora hyacinthus dan Acropora millepora. Jenis-jenis ini umumnya ditemukan di hampir seluruh perairan Indonesia (Suharsono, 2010) dan berada pada perairan yang jernih dan sedikit berarus, sebab jenis Acropora sangat membutuhkan arus dan ombak yang cukup untuk membersihkan dirinya, karena jenis ini memiliki polip yang kecil (Manuputty, 1990).

Kecilnya nilai indeks keanekaragaman jenis $(\mathrm{H})$ di Stasiun 5, disebabkan karena lokasi ini memiliki jumlah jenis yang paling sedikit dibandingkan dengan lokasi lain yaitu 12 jenis dan diwakili oleh marga Porites jenis Porites cylindrica, Porites nigrecens dan Porites rus. Marga Porites merupakan karang keras yang umumnya mempunyai kemampuan yang cukup tinggi beradaptasi dengan kondisi lingkungan perairan dan bisa hidup pada perairan jernih sampai agak keruh. Kurangnya kehadiran jenis karang keras di lokasi Stasiun 5 lebih dipengaruhi oleh ombak serta arus yang keras terutama musim angin utara dan angin barat, dimana lokasi ini mendapat tekanan yang cukup kuat dari perairan Laut Sulawesi karena letaknya berada pada ujung paling luardari gugusan pulau Tiga (Gambar 1).Berdasarkan tinggi rendahnya nilai indeks keanekaragaman jenis $(\mathrm{H})$ karang keras diatas menunjukkan bahwa status karang keras masuk kategori rendah sampai sedang atau tidak stabil sampai moderat. Walaupun demikian berdasarkan nilai keanekaragaman jenis juga menunjukkan karang keras di perairan ini masuk kriteria produktif sampai sangat produktif.

Indeks kemerataan jenis (E) karang keras lokasi pengamatan perairan kabupaten Bolaang Mongondow menunjukkan nilai tertinggi ditemukan di Stasiun 1 sebesar 0,86 dan terendah di Stasiun 6 sebesar 0,76 (Gambar 5). Tingginya nilai kemerataan jenis (E) di Stasiun 1 menunjukkn sebaran jenis-jenis karang keras di lokasi ini merata dengan jumlah taksonnya bervariasi dan tidak ada perbedaan jumlah individu yang menyolok antar jenis karang keras. Pola sebaran karang keras di Stasiun 1 sangat variatif dan tidak hidup dalam bentuk kelompok (patches), sebaliknya di Stasiun 6 menunjukkan pola berkelompok terutama jenis Porites 
cylindrica yang ditemukan dalam jumlah individu yang tinggi dibandingkan dengan jenis karang keras yang lain. Porites cylindrica merupakan jenis karang keras yang umum dijumpai di seluruh perairan Indonesia terutama di tempat yang dangkal atau rataan terumbu (Suharsono, 2010). Veron (1986) menyatakan bahwa karang Porites cylindrica mempunyai sebaran yang cukup luas dan ditemukan di seluruh perairan Great Barrier Reef (GBR) Australia.Sebaran karang keras dipengaruhi oleh aspek ekologiseperti kondisi fisik, bentuk dasar dan substrat dasar perairan serta aspek biologi menyangkut kemampuan jenis karang keras menghadapi perubahan kondisi lingkungan, kemampuan berkembang biak dan kemampuan berkompetisi untuk mempertahankan hidup. Umumnya karang keras yang ditemukan di lokasi Stasiun 1 mulai tampak pada kedalaman $0,5 \mathrm{~m}$ pada rataan terumbu sampai kedalaman $12 \mathrm{~m}$. Walaupun ada perbedaan nilai kemerataan jenis (E) lokasi Stasiun 1 dan Stasiun 6 tetapi berdasarkan kriteria keduanya masuk kategori komunitas stabil.

Hasil analisis indeks dominansi (D) menunjukkan nilai tertinggi ditemukan di Stasiun 7 sebesar 0,20 dan terendah di Stasiun 1 sebesar 0,11.Tingginya nilai dominansi di Stasiun 7 menunjukkan adanya dominasi dari jenis karang keras tertentu dan sebaliknya di Stasiun 1 tidak ada dominasi jenis karang keras. Berdasarkan jumlah individu di Stasiun 7 ditemukan karang keras jenis Porites cylindrica sebanyak 25 individu sedangkan jenis lain jumlahnya dibawah 6 individu. Sebaliknya di Stasiun 1 hampir tidak ada perbedaan jumlah individu antar jenis karang keras karena ditemukan dibawah 5 individu. Porites cylindrica merupakan jenis karang keras yang berlimpah ditemukan hidup pada kedalaman 5-10m, dengan pola sebaran dalam bentuk koloni yang besar dan biasanya mendominasi suatu perairan serta mampu beradaptasi terhadap perubahan lingkungan seperti kekeruhan dan lainnya. Tomascik \& Sander (1987) menemukan karang Porites yang hidup di perairan yang mengalami eutrofikasi memiliki kemampuan bertahan terhadap sedimentasi yang lebih rendah dibandingkan pada perairan yang alami. Walaupun demikian tingginya nilai dominansi (D) karang keras di Stasiun 7 berdasarkan kriteria masuk kategori rendah karena nilai dominansinya di bawah 0,50 .

Hasil perhitungan persentase tutupan jenis karang keras di perairan kabupaten Bolaang Mongondow berkisar dari 63,40\% (Stasiun 4) sampai 86,24\% (Stasiun 3) (Tabel 4). Tingginya nilai persentase tutupan karang keras di Stasiun 3, karena lokasi ini memiliki karakteristik perairan yang jernih dan berada pada posisi yang terlindung dari hempasan ombak sehingga karang dari marga Acropora maupun non-Acropora dapat tumbuh dengan baik. Tabel 4 menunjukkan adanya keseimbangan pertumbuhan antara karang Acropora dan non-Acropora yang cukup baik (Stasiun 3 )dibandingkan dengan lokasi lain dimana ada yang mempunyai pertumbuhan karang keras marga Acropora yang tinggi dibandingkan dengan non-Acropora (Stasiun 1) atau sebaliknya karang non-Acropora lebih tinggi dari karang Acropora (Stasiun 2).

Berdasarkan nilai persentase tutupan karang keras yang ditemukan di perairan kabupaten Bolaang Mongondow dalam hubungan dengan penentuan kondisinya berdasarkan standart kategori penilaian yang dikemukakan oleh Gomez dan Alcala (!978), menunjukkan karang keras lokasi ini masuk kategori baik sampai sangat baik dengan nilai reratanya sebesar 77,88\% (kategori sangat baik).Rerata nilai persentase tutupan karang keras lokasi ini lebih tinggi dibandingkan dengan beberapa lokasi di perairan Sulawesi Utara seperti di pulau Siladen, pulau Gangga, pulau Tagulandang dan perairan desa Tumbak, kabupaten Minahasa Tenggara. 


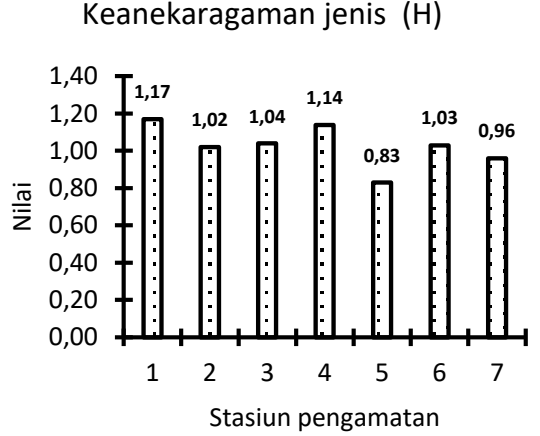

(A)

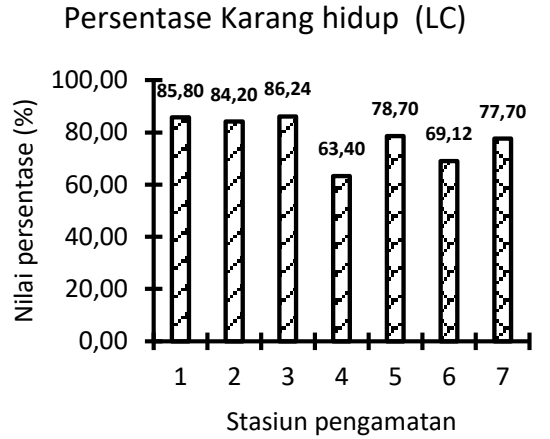

(B)

Gambar 6. Nilai keanekaragaman jenis (A) dan persentase karang hidup (B) stasiun pengamatan perairan Kabupaten Bolaang Mongondow, Februari 2019.

Mencermati Gambar 6 diatas menunjukkan adanya hubungan yang terbalik antara nilai keanekaragaman jenis $(\mathrm{H})$ dengan persentase tutupan karang keras yang ditemukan di perairan kabupaten Bolaang Mongondow. Nilai indeks keanekaragaman jenis (A) tertinggi ditemukan di Stasiun 1, tetapi memiliki nilai persentase tutupan (B) yang rendah dibandingkan Stasiun 3 yang memiliki nilai persentase tutupan yang tertinggi. Sebaliknya nilai persentase tutupan (B) terendah ditemukan di Stasiun 4, tetapi memiliki nilai keanekaragaman jenis (A) tertinggi kedua setelah Stasiun 1. Hal ini terjadi karena di Stasiun 1 memiliki jumlah jenis yang terbanyak (23 jenis) dibandingkan Stasiun 3 (19 jenis), tetapi memiliki panjang koloni karang keras tertinggi (4312cm) dibandingkan dengan panjang koloni di Stasiun 1 (4290cm). Grigg \& Saragos (1974) dalam Moll (1983) menyatakan bahwa hubungan positif dan negatif antara persentase tutupan dan indeks keanekaragaman jenis tergantung dari faktor fisik dan biologi perairan. Parameter lingkungan yang merupakan faktor fisik seperti salinitas, suhu, kedalaman air, aksi gelombang, cahaya, sedimen dan pola sirkulasi samudera sangat berperan dalam perkembangan karang keras. Secara biologis, kemampuan karang keras untuk mendapatkan makanan, melakukan perkembangbiakan, pertumbuhan serta melakukan kompetisi ruang (sifat agresi) bertujuan untuk mendapatkan ruang yang luas agar pertumbuhan koloninya lebih besar dan cepat dari jenis lainnya (Veron, 1986).

Ukuran panjang koloni karang keras perairan kabupaten Bolaang Mongondow (Tabel 5) menunjukkan suku Poritidae mempunyai total panjang koloni yang tertinggi sebesar $14761 \mathrm{~cm}$ atau 54,15\% dari total panjang koloni karang yang ditemukan $(27258 \mathrm{~cm})$. Disusul suku Acroporidae dengan total panjang $5763 \mathrm{~cm}$ atau $21,14 \%$ dari total panjang koloni. Suku Merulinidae memiliki panjang koloni terendah $(45 \mathrm{~cm})$ karena hanya diwakili oleh satu jenis yaitu Merulina ampliata yang berbentuk daun (foliose) sehingga mudah patah dan kalah dalam kompetisi merebut ruang pertumbuhan.Walaupun demikian jenis Merulina ampliata merupakan karang keras yang tersebar di seluruh perairan Indonesia, umumnya dijumpai mulai dari daerah tubir hingga kedalaman lebih dari tiga meter (Suharsono, 2010).Suku Poritidae yang ditemukan didominasi oleh marga Porites dengan bentuk koloni bercabang dan masif dan tersebar sepanjang garis pantai di semua stasiun pengamatan. Suharsono (2010) menyatakan karang marga Porites merupakan karang yang umum ditemukan hampir di seluruh perairan Indonesia.

Gambar 7 tentang jumlah individu (A) dan panjang koloni (B) sepuluh jenis karang keras yang dominan ditemukan di perairan kabupaten Bolaang Mongondow menunjukkan adanya 


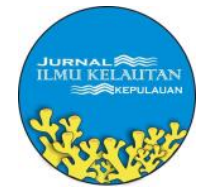

perbandingan terbalik dimana jumlah individu terbanyak belum tentu memiliki panjang koloni yang tertinggi atau sebaliknya jumlah individu terendah memiliki panjang koloni yang terendah.

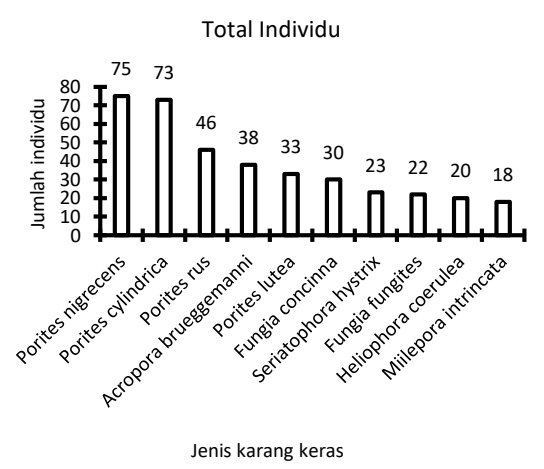

(A)

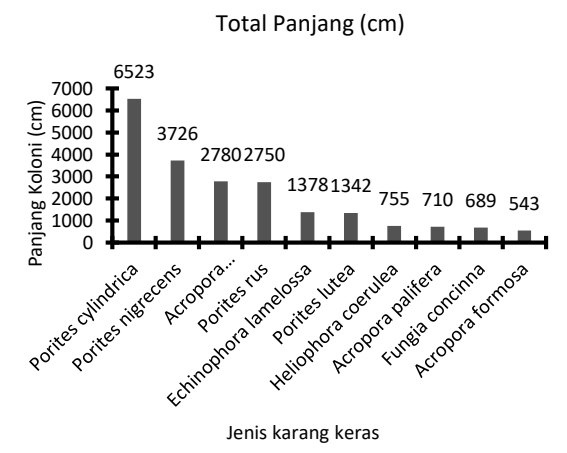

(B)

Gambar 7. Grafik total individu (A) dan total panjang koloni(cm) (B)10 jenis karang keras yang dominan ditemukan di perairan Kabupaten Bolaang Mongondow, Pebruari 2019.

Hal ini dapat dilihat pada jenis Porites nigrecens yang mempunyai jumlah individu tertinggi tetapi mempunyai panjang koloni yang rendah dibandingkan dengan jenis Porites cylindrica yang memiliki panjang koloni tertinggi tetapi memiliki jumlah individu yang rendah. Panjang koloni jenis karang keras tertentu biasanya dipengaruhi oleh pola kompetisi dalam merebut ruang terhadap jenis yang lain.

\section{Kesimpulan}

Berdasarkan analisis data hasil dan pembahasan data transek karang keras dari perairan kabupaten Bolaang Mongondow memiliki keanekaragaman jenis karang keras yang cukup tinggi dengan pola sebaran yang cukup merata dan tutupannya mendominasi perairan pesisir lokasi pengamatan sebesar $77,88 \%$ masuk kategori sangat baik. Secara umum karang keras perairan kabupaten Bolaang Mongondow didominasi oleh karang bercabang non-Acropora dan marga Acropora, karang jamur (fungiidae) dan karang merayap (encruisting).

\subsection{Saran}

Penelitian struktur komunitas danpanjang koloni keras yang dilakukan di Perairan Kabupaten Bolaang Mongondow ini,belum menjangkau secara keseluruhan wilayah pesisir kabupaten. Diharapkan perlu adanya penelitian lanjutan untuk lokasi-lokasi yang belum terjangkau, agar hasilnya dapat lebih baik dan sekaligus untuk melihat jenis, sebaran serta luasan tutupan karang keras secara keseluruhan.

\subsection{Persantunan}

Penulis mengucapkan terima kasih kepada Kepala Loka Konservasi Biota Laut-LIPI Bitung dan juga kepada Dr. Teguh Peristiwady yang telah memberikan kesempatan kepada penulis dalam pengambilan data lapangan. Saudara Simon Patty yang sudah membantu pengambilan data oseanografi serta pembuatan peta dan teman-teman Loka Konservasi Biota Laut-LIPI Bitung yang telah berpartisipasi dalam kegiatan penelitian Biodiversitas perairan Kabupaten Bolaang Mongondow tahun 2019 yang didanai dari DIPA Loka Konservasi Biota Laut-LIPI Bitung tahun 2019. 


\section{Daftar Pustaka}

Abrar, M., I. Bachtiar dan A. Budiyanto. 2012. Struktur komunitas dan penyakit pada karang (Scleractinia) di perairan Lembata, Nusa Tenggara Timur. Ilmu Kelautan, 17 (2) : 109 $-118$.

Chave, K. E. 1973. What is a coral reef ?. In ;Atlas of Kaneohe Bay; A reef ecosystem under stress. The University Hawaii Sea Grant Program : 15 - 16.

Ditlev, H. 1980. A field-guide to the reef-building coral of the Indo-Pasific. Scandinavian Science Press Ltd. Klampenborg: 291 pp.

English, S., C. Wilkinson and V. Baker. 1997. Survey manual for tropical marine resources. Second edition. Australian Institute of Marine Science. Townsville: 390 pp.

Gomez, E.D. \& A.C. Alcala. 1978. Stastus of Philiphina coral reef. Project, Int. Symp. Biogeogr. Evol. S. Hem. Auckland New Zealand, 17 - 20 July 1978. 2: 663-669.

Hermanto, B. 2014. Struktur komunitas karang jamur (Fungiidae) di perairan pulau Gangga, Sulawesi Utara. Oseanologi dan Limnologi di Indonesia, 40 (2): 169-179.

Huang. Z and L. Mao. 2012. The living species and their illustrations in China's Seas (Part II). An illustrated guide to species in China's Seas. Volume 3. $441 \mathrm{pp}$.

Indarjo, A., W. Wijatmoko dan Munasik. 2004. Kondisi terumbu karang di perairan Pulau Panjang, Jepara. Ilmu Kelautan, 9 (4): 217 - 224.

Loya, Y. 1972. Community structure and species diversity of hermatypic corals at Eilat. Red Sea. Mar. Biol. 13 (2): 100-123.

Manuputty, A. E. 1990. Sebaran keanekaragaman dan komposisi jenis karang batu di perairan Kabil. Soemodihardjo, S.S. Birowo dan K. Romimohtarto (Eds). Perairan Pulau Batam. Pusat Penelitian dan Pengembangan Oseanografi LIPI, Jakarta. 15 - 23.

Moll, H. 1983. Zonation and diversity of Scleractinian on reef of S. W. Sulawesi, Indonesia. Thesis, Leiden. 107 pp.

Nybakken, J. W. 1992. Biologi laut, suatu pendekatan ekologis. Alih Bahasa ; H. M. Eidman, Koesoebiono, D. G. Bengen, M. Hutomo \& S. Sukardjo. Penerbit PT. Gramedia. Jakarta. 459 hal.

Odum, E.P. 1971. Fundamental of ecology. W. E. Sunders, Philadelphia : 574 hlm.

Salm, R. V \& J. R. Clarck. 1989. Marine and coastal protected areas. A guide for planner and managers. International Union for Conservation of Nature and Natural Resources. Gland, Switzerland. 302 pp.

Siringringo, R. M. 2008. Perubahan komunitas karang batu pasca gempa di Pulau Nias. Dalam: Sumberdaya laut di perairan Pantai Barat Sumatera. Pusat Penelitian OseanografiLIPI, Jakarta: LIPI Press; 1 -13.

Souhoka, J. 2007. Sebaran dan kondisi Karang Batu (Hard Coral) di perairan Tanjung Merah Bitung, Sulawesi Utara. Oseanologi dan Limnologi di Indonesia, 33 (3): 393-411.

Souhoka, J. 2012. Kondisi Karang Batu di perairan Pulau Mantihage Kabupaten Minahasa Utara, Propinsi Sulawesi Utara. Biota Jurnal Ilmiah Ilmu-Ilmu Hayati, 17 (3): 153-164.

Souhoka, J. 2014. Struktur komunitas karang batu (scleractinia) di perairan Tagulandang, Sulawesi Utara. J. Oseanologi dan Limnologi di Indonesia, 40(2): 189-202. 
JURNAL ILMU KELAUTAN KEPULAUAN, 2 (2) ;55-73, DESEMBER 2019

Suharsono. 2010. Jenis-jenis karang di Indonesia. Lembaga Ilmu Pengetahuan Indonesia. COREMAP PROGRAM, Jakarta. $372 \mathrm{hlm}$.

Sukarno, M. Hutomo, M.K. Moosa dan P. Darsono. 1981. Terumbu karang di Indonesia. Sumberdaya, permasalahan dan pengelolaannya. Proyek Penelitian Potensi Sumberdaya Alam Indonesia. Lembaga Oseanologi Nasional, Lembaga Ilmu Pengetahuan Indonesia, Jakarta: $112 \mathrm{hlm}$.

Tomascik, T and F. Sander. 1987. Effect of eutrophication on reef-building corals III. Reproduction of the reef-building coralPorites porites. Marine Biology, 94: 77-94.

Veron, J.N. 1986. Coral of Australian and the Indo - Pasific. University of Hawaii Press. Honolulu. 644 pp.

Widinugraheni, P. 1993. Distribusi spasial karang Scleractinia dan hubungannya dengan karakteristik habitat di pantai Belebu dan pulau Sekepal, Lampung Selatan. Skripsi Program Studi Ilmu dan Teknologi Kelautan Fakultas Perikanan, Institut Pertanian Bogor. 90 hal. 